Vol 2 No 1, November 1995

\title{
THE COPYRIGHT LAW AND PAPUA NEW GUINEA
}

'Papua New Guineans would not be impressed by fancy arguments advanced elsewhere -- that it is immoral to copy somebody else's work and that a country should adopt copyright laws to enhance its international standing.'

\section{By JOHN NONGGORR}

EVERYBODY having an interest in copyright law first, and Papua New Guinea second, is well aware by now of the fact that Papua New Guinea has a copyright law that was passed in 1978 but that it has not been brought into force. I discussed the background to the Act and the reasons why it has not been brought into force in a seminar held in Port Moresby in 1991 and the main points of which were published in a legal journal.(1) In another article I wrote for Intellectual Property in the Asia and Pacific, I recounted the efforts made since then by individuals and industry to debate the issue with the objective of ensuring the adoption of copyright legislation for Papua New Guinea.(2)

\section{The costs and benefits of copyright law}

The important issue for Papua New Guinea is not what form a copyright law should take or what type of materials or works a copyright law should protect and so on. These are issues of detail that can easily be sorted out, some requiring specific instructions, and hence policy decisions while others of a technical nature for the legal technicians. I might add also that the drafting of appropriate legislation is not a problem.

The most important question on copyright law in Papua New Guinea and, which question that must be decided by the people of PNG, if copyright legislation is to be introduced, is whether this will result in increasing the costs of educating children; whether the prices of foreign songs in cassette tapes and CDs which our people --especially the young -- have come to love, sold in shops around Papua New Guinea will increase; whether the costs of using a computer in the office will increase. It is these basic questions -- its likely impact on the ordinary Papua New Guinean -- that are the crucial questions for us to address.

I have stressed before that, in the final analysis, the decision about whether copyright legislation is introduced must depend on the benefits to Papua New Guinea, as a whole, of having a copyright law. I am not impressed and I doubt other Papua New Guineans would be impressed by fancy arguments advanced elsewhere about morality -- that it is immoral to copy (or 'steal') 
somebody else's work and that a country should adopt copyright laws to improve or enhance its international standing in the community of nations.

Obviously, the Papua New Guineans (both individuals and corporate entities) producing copyright work and who would benefit from having a copyright law introduced by legislation, are small but growing. The music industry has really taken off in the last few years, especially with the growth of television in this country. Papua New Guinea now can boast of having talented song writers, musicians and producers with a number of modern class studios. With the introduction of television, Papua New Guineans are potential owners of all types of copyright material, from advertisement jingles to full programs aired on the local station. The literary industry also has shown promise, for example, in the use of locally produced school curricula in other countries.

The benefits of these developments, in terms not only of revenue generation for the individuals and the country but also in terms of the provision of employment, the incentive to encourage creativity and in turn the reduction into permanent form of the diverse and rich cultures of the country, need to be weighed against the costs of educating our children and meeting our populations desire for Western music and the use of computer programs that are now becoming indispensable in the offices of all types.

Again, I would call on the making of this cost analysis, for that is the issue that was important when the Copyright Act 1978 was passed and, I suggest, it is the question that must be addressed now and in the future, if the question of enacting copyright legislation is passed. In 1978, it was clear that a copyright law could not be justified as Papua New Guinea stood to lose more than it could expect to benefit. One cannot say the same today. Certainly the scale may now be equally balanced or it may go the other way.

The important question is to establish if the benefits that a copyright law will bring will offset the costs. In other words, the revenue generated, the employment opportunities created, the creativity encouraged, the benefit of reducing the varied and rich local cultures into permanent form, etc outweigh the costs of education to our children and the increase in prices of foreign recorded songs in cassette tapes or CDs. This cost/benefit analysis must necessarily be done at the national and not the individual level.

It will be recalled that the reason why the 1978 Copyright Act has been shelved up to now is because of its perceived costs to the educational institutions -- the costs of educating our children (and adults). But today, this cost may not be as much as it is feared. Educational institutions continue to buy textbooks or other foreign books. But, it is the copying of material that we are concerned with. When a student buys a textbook, he or she is paying the full price that a student in Australia would pay. The benefit only comes when educational institutions make copies of that book or parts of such book to make available to students which would not be permitted if a copyright law with international protection existed. I know that this is still done at the University of Papua New Guinea but I do not know how much of this practice currently prevails. I also do not know how much of this is done in other educational institutions -- primary, secondary and tertiary institutions -- in the country. 


\section{The form of legislation}

As indicated earlier, the detailed issues of what form a copyright law should take and what its details should be are, at this stage, not so crucial. On the question of form, what is important, I consider, is whether a copyright legislation for Papua New Guinea should give copyright protection to only Papua New Guinean material (or works, using the legal terminology) and enforced only within the country or should there be international protection as well. This is the second important question that requires an answer in addition to the issue of the costs and benefits of adopting copyright legislation in the country. The two issues are related in that the cost/benefit analysis needs to be done using firstly the scenario where the legislation will apply only within Papua New Guinea and secondly, where there will be international protection through Papua New Guinea joining any of the existing international copyright convention regimes.

The 1978 Copyright Act provided for domestic copyright law only as it provided a deposit system, which would not have accorded with international coverage $\mathrm{r}$ gimes. The National Information and Communication Policy of the Government follows that line as it speaks of a domestic copyright law.

Enacting a domestic copyright law is a non-issue. If the requirements for unnecessary deposits, etc which would be costly and administratively cumbersome to administer, are done away with and we draft a simple copyright Act that confers protection on creation and publication, this would be beneficial to the country. I say that it is a non-issue because there is probably nobody against this. Everybody would be for it and if we wanted this in fact, we should have had this in 1978 after doing away with the deposit requirements. The practice by foreign owners of copyright work who publish their works at a number of countries at the same time to attract (as the first publication attracts copyright protection in that country) may do so in Papua New Guinea but this may be regulated in the domestic legislation.

The real issue concerns international protection. The issue is this: if Papua New Guinea wants its copyright material (books, music, etc) produced by Papua New Guineans to be protected in Australia, New Zealand, the United States and other countries so that they are not copied by people there and exploited commercially or otherwise, it must join an international scheme providing such protection. There are two major international Conventions - the Berne Convention and the Universal Copyright Convention. But, in order to join those schemes, Papua New Guinea's copyright law must meet the standards set by those conventions. One of the important standards is the observance of reciprocity -- that is, Papua New Guinea must give protection to all copyright works of the other countries which are members of the Convention. The other standard is that formalities such as depositing of material to attract copyright is not allowed.

That issue needs to be decided first and foremost. The details can come later.

\section{Notes:}

1. John Nonggorr, 'Introduction of Copyright Law in Papua New Guinea', Melanesian Law Journal, Vol 18, 1990. 
2. See Nonggorr, Intellectual Property in the Asia and the Pacific journal, World Intellectual Property Organisation (WIPO), 1992.

- Professor John Nonggorr is Professor at Law in the Faculty of Law, University of Papua New Guinea. This paper was presented at a UNESCO Copyright Seminar at the National Library of Papua New Guinea, 26 January 1995. 